\title{
Perbandingan Metode Certainty Factor dan Theorema Bayes dalam Mendiagnosa Penyakit Kandidiasis pada Manusia Menggunakan Metode Perbandingan Eksponensial
}

\author{
Zaimah Panjaitan', Hafizah', Rico Imanta Ginting ${ }^{2}$, Amrullah ${ }^{1}$ \\ ${ }^{1}$ Prodi Sistem Informasi, STMIK Triguna Dharma, Medan, Indonesia \\ ${ }^{2}$ Prodi Teknik Komputer, STMIK Triguna Dharma Medan, Indonesia \\ Email: 1," zaimahp09@gmail.com, ${ }^{2}$ hafizah22isnartiilyas@gmail.com, ${ }^{3}$ imantarico@gmail.com, \\ ${ }^{4}$ amrullahmedan1@gmail.com \\ Email Penulis Korespondensi: zaimahp09@gmail.com
}

\begin{abstract}
Abstrak-Kandidiasis adalah penyakit infeksi yang disebabkan oleh jamur candidia. Penelitian tentang jamur ini sudah banyak dilakukan hingga ditemukan beberapa jenis jamur candidia yang dapat menyerang dan menyebabkan infeksi pada manusia. Jenis penyakit kandidiasis juga beragam, namun dapat digolongkan secara umum menjadi tiga jenis yaitu yang menyerang mulut (Candidiasis Thrush), vagina (Candiasis Vulvoginal), dan kulit (Candidiasis Cutaneous). Penyakit kandidiasis sangat rentan menjangkit dan menular, oleh karena itu dibutuhkan sebuah study untuk mendiagnosa penyakit kandidiasis. Dewasa ini sistem pakar sering digunakan untuk mendiagnosa penyakit. Ada beberapa metode yang umum digunakan dalam kepakaran diantaranya metode Certainty Factor dan Theorema Bayes. Namun masalah yang dihadapi dalam mengimplementasikan sistem pakar pada bidang apapun adalah faktor ketidakpastian. Hal ini disebabkan oleh keraguan pengguna dalam menjawab pertanyaan saat sesi konsultasi atau bahkan ketidaktepatan metode yang digunakan dalam membangun sistem. Oleh karena itu perlu dipelajari dan dibandingkan metode yang dapat digunakan untuk membangun sistem. Perbandingan eksponensial merupakan metode perbandingan sederhana yang mampu mengurangi bias dalam proses analisa yang dilakukan. Penelitian ini bertujuan untuk menerapkan dan menganalisa kedua metode tersebut dan membandingkan hasilnya dengan metode perbandingan eksponensial dalam mendeteksi penyakit kandidiasis pada manusia. Hasil dari penelitian ini didapatkan bahwa kedua metode tersebut mencapai hasil yang sama yaitu tingkat persentase terendah ada pada penyakit Candidiasis Truth, kemudian Candidiasis Vuvoginal, dan yang paling tinggi Candidiasis Cutaneous. Dari kedua metode ini, Certanty Factor lebih akurat dalam mendiagnosa penyakit kandidiasis.
\end{abstract}

Kata Kunci: Sistem Pakar; Certainty Factor; Theorema Bayes; Perbandingan Eksponensial; Kandidiasis

Abstract-Candidiasis is an infectious disease caused by the fungus candida. Research on this fungus has been widely carried out until several types of candida fungi are found that can attack and cause infections in humans. Types of candidiasis also vary, but can be classified in general into three types, namely attacking the mouth (Candidiasis Thrush), vagina (Vulvoginal Candidiasis), and skin (Cutaneous Candidiasis). Candidiasis is very susceptible to infection and infection, therefore a study is needed to diagnose candidiasis. Today, expert systems are often used to diagnose diseases. There are several methods commonly used in expertise, including the Certainty Factor method and the Bayes Theorem. However, the problem faced in implementing an expert system in any field is uncertainty. This is caused by the user's hesitation in answering questions during the consultation session or even the inaccuracy of the methods used in building the system. Therefore, it is necessary to study and compare the methods that can be used to build the system. Exponential is a simple comparison that can reduce bias in the analysis process. This study aims to apply and analyze both methods and the results compare with an exponential comparison in detecting candidiasis in humans. The results of this study showed that both methods achieved the same results, namely the lowest percentage level was Candidiasis Truth, then Vuvoginal Candidiasis, and the highest was Candidiasis Cutaneous. Of these two methods, Certanty Factor is more accurate in diagnosing candidiasis.

Keywords: Expert System; Certainty Factor; Theorema Bayes; Exponential Comparison; Candidiasis

\section{PENDAHULUAN}

Kandidiasis merupakan suatu bentuk penyakit yang dapat menyerang manusia yang disebabkan oleh infeksi jamur berjenis candida. Infeksi yang menjangkit dapat berupa infeksi berat atau infeksi invasif. Infeksi ini berkembang menjadi penyakit kandidemia, kandidiasis diseminata, endocarditis, meningitis, endofalmitis, serta infeksi pada organ dalam lainnya[1]. Penyakit berupa infeksi oleh jamur merupakan penyakit yang tidak bisa dianggap ringan, pada beberapa jenis candidia dapat menurunkan sistem imun pada manusia atau hewan yang dijangkit[2]. Penyakit ini sangat mudah menjangkit, faktor penyebab penyakit ini juga sangat dekat dengan kehidupan manusia seperti faktor iklim dan faktor kebersihan. Berdasarkan penelitian yang dilakukan pada 25 responden di RSUD Dr.H.Abdul Moeloek Provinsi Lampung Tahun 2013 bahwa beberapa faktor dapat berpengaruh terhadap penyakit kandidiasis yaitu berupa kebersihan pakaian, kebersihan kulit, kebersihan tangan dan kuku, kebersihan genitalia, kebersihan handuk, dan kebersihan tempat tidur[3].

Dalam kehidupan modern, sistem pakar telah digunakan pada banyak bidang seperti pertanian, peternakan, kedokteran dan lain sebagainya. Namun masalah yang dihadapi dalam mengimplementasikan sistem pakar pada bidang apapun adalah faktor ketidakpastian. Hal ini disebabkan oleh keraguan pengguna dalam menjawab pertanyaan saat sesi konsultasi atau bahkan ketidaktepatan metode yang digunakan dalam membangun sistem. Oleh karena itu, untuk meminimalisir faktor ketidakpastian tersebut maka selalu digunakan metode Certainty Factor karena metode ini berisi nilai untuk mengukur tingkat kepercayaan ahli[4]. Disisi lain, 
untuk meminimalisir tingkat ketidakpastian tersebut banyak juga digunakan metode Theorema Bayes karena pada metode ini dihitung probabilitas terhadap suatu masalah berdasarkan pengaruh dari hasil observasi yang dilakukan di lapangan[5].

Begitu juga pada penyakit kandidiasis, sistem pakar dapat diterapkan dalam mendiagnosa penyakit kandidiasis. Mengingat bahwa penyebab penyakit ini sangat bersinggungan dengan kehidupan sehari-hari serta penularannya yang sangat mudah, maka diperlukan sistem pakar untuk mendiagnosa penyakit ini. Metode yang biasa dipakai dalam mendiagnosa penyakit seperti Certainty Factor atau Theorema Bayes dapat menjadi alternatif. Pada penelitian sebelumnya, telah banyak dilakukan penelitian sejenisnya seperti sistem pakar diagnosa influenza pada anak dengan metode Certainty Factor[6], sistem pakar mendiagnosa gangguan fungsi kardiovaskular dengan metode Theorema Bayes[7], dan masih banyak penelitian sejenis.

Untuk menetapkan metode mana yang paling tepat untuk digunakan dalam mendiagnosa penyakit kandidiasis, maka perlu dilakukan studi dan perbandingan terhadap kedua metode tersebut. Pada beberapa penelitian sebelumnya telah dilakukan perbandingan metode Certainty Factor dengan metode lain seperti perbandingan metode Certainty Factor dan Theorema Bayes dalam mendiagnosa penyakit angina pektoris menggunakan metode perbandingan eksponensial[8], perbandingan Certainty Factor dan Forward Chaining untuk Diagnosis Dini Penyakit Kulit Kucing[9], analisa perbandingan metode Certainty Factor dan Dempster Shafer pada sistem pakar diagnosa penyakit Diabetes Melitus[10], dan perbandingan efektifitas Certainty Factor dan Dempster-Shafer dalam penentuan gaya belajar remaja[11].

Pada penelitian ini akan dibahas bagaimana cara menerapkan sistem pakar dengan membandingkan metode Certainty Factor dan Theorema Bayes. Kedua metode tersebut akan diuraikan secara terperinci dalam mendiagnosa penyakit kandidiasis dengan sampel penelitian yang sama. Kemudian dari hasil penelitian kedua metode tersebut akan dilihat dengan perbandingan eksponensial yang mana diantara kedua metode tersebut yang paling baik dan cocok untuk digunakan oleh peneliti selanjutnya dalam membangun sistem pada masalah serupa.

Penelitian ini berkontribusi dalam memberikan pengetahuan baru kepada peneliti berikutnya tentang metode yang sebaiknya digunakan dalam kasus serupa. Selain itu, peneliti berikutnya dapat menerapkan metode yang paling akurat dalam mendiagnosa penyakit kandidiasis untuk kemudian membangun sistem berupa program yang dapat digunakan untuk membantu masyarakat dalam mendiagnosa penyakit kandidiasis.

\section{METODOLOGI PENELITIAN}

\subsection{Kerangka Penelitian}

Dalam penelitian ini dilakukan beberapa proses yang dapat dilihat sebagai berikut:

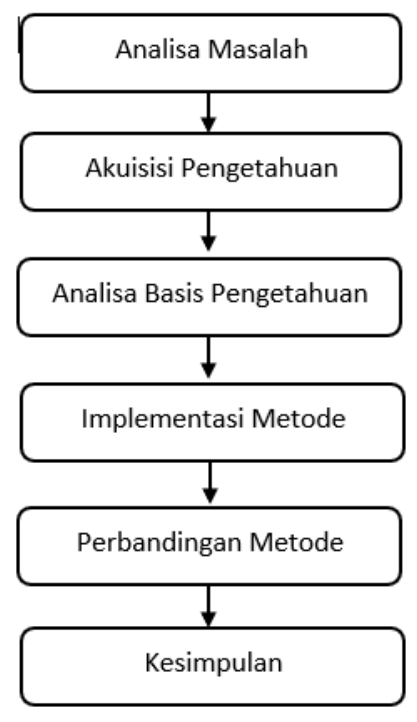

Gambar 1. Kerangka Penelitian

Pada gambar 1 di atas, dapat dijelaskan, sebagai berikut:

1. Pertama sekali dilakukan analisa terhadap permasalahan yaitu jenis-jenis penyakit kandidiasis.

2. Kemudian selanjutnya dilakukan tahapan akuisisi pengetahuan pakar berupa gejala-gejala berdasarkan indikasi penyakit pada kasus kandidiasis. Pada tahap ini juga dilakukan analisa terhadap 175 sampel pasien yang terinfeksi penyakit kandidiasis.

3. Pada tahap ini dilakukan analisa basis pengetahuan berupa nilai MB dan MD setiap gejala yang dialami oleh pasien untuk metode Certainty Factor dan nilai probabilitas berdasarkan kejadian untuk metode 
ISSN 2614-5278 (media cetak), ISSN 2548-8368 (media online)

Available Online at https://ejurnal.stmik-budidarma.ac.id/index.php/mib

DOI 10.30865/mib.v5i3.3078

Theorema Bayes dari 175 pasien tersebut.

4. Selanjutnya dilakukan implementasi metode Certainty Factor dan Theorema Bayes terhadap seorang pasien yang mengalami gejala-gejala kandidiasis

5. Kedua hasil penerapan metode tersebut dibandingkan dengan menggunakan teori perbandingan eksponensial

6. Dari semua tahap di atas, diambil kesimpulan.

\subsection{Kajian Pustaka}

Penyakit yang diakibatkan infeksi jamur merupakan penyakit yang sering menjangkit manusia. Berbagai jenis jamur dapat menyebabkan penyakit pada manusia. Kandidiasis merupakan salah satu jenis jamur yang dapat menyerang manusia. Telah ditemukan bahwa jamur ini juga memiliki jenis yang bermacam-macam dan mengakibatkan jenis penyakit yang bermacam pula. Secara umum penyakit kandidiasis dapat digolongkan ke dalam tiga jenis yaitu Candidiasis Thrush, Candidiasis Vulvoginal, dan Candidiasis Cutaneous. Candidiasis Thrush merupakan jenis kandidiasis yang menyerang area mulut manusia. Jenis jamur candida yang dapat menyerang mulut adalah Kandida Albikan, Candida Parapsilosis, Candida Tropicalis, Candida Glabrata, dan Candida Guillermondii. Jenis-jenis candida ini adalah organisme dari flora mulut dan dapat menimbulkan infeksi jika ada faktor pendukung[12]. Kandidiasis mulut dan tenggorokan, juga dikenal sebagai "sariawan" atau kandidiasis orofaringeal (OPC), atau oral moniliasis, adalah infeksi jamur yang terjadi ketika ada pertumbuhan berlebih dari Candida albicans. Biasanya ditemukan di kulit atau selaput lendir. Namun, jika lingkungan di dalam mulut atau tenggorokan menjadi tidak seimbang, Candida bisa berkembang biak. Kemudian Candidiasis Vulvoginal merupakan penyakit yang sangat sering menjangkit wanita dalam masa produktif. Kandidiasis Vulvovaginalis merupakan suatu infeksi pada area vagina dan vulva yang disebabkan oleh jamur Candida baik spesies Candida albicans maupun Candida non-albicans. Sebanyak 70-75\% wanita minimal sekali seumur hidup pernah mengalami infeksi ini terutama pada saat usia reproduktif aktif dan sekitar 10-15\%[13]. Candidiasis Cutaneous atau disebut juga kandidiasis kulit merupakan penyakit pada kulit yang disebabkan oleh infeksi jamur candida. Sistem pakar sebagai solusi permasalahan dalam kehidupan modern menghadirkan banyak metode yang dapat diimplementasikan dalam mendeteksi penyakit termasuk penyakit kandidiasis. Sistem pakar membantu memudahkan manusia dalam mengambil keputusan atau dalam pemecahan masalah. Setiap metode di dalam sistem pakar pastinya memiliki kelebihan dan kekurangan serta memiliki ciri tertentu yang dapat disesuaikan oleh pemakainya dalam menyelesaikan masalah. Sistem pakar tidak akan membuat pakar menjadi tidak lagi dibutuhkan, jauh daripada itu justru sistem pakar akan membantu pakar dalam menganalisa sebuah permasalahan serta dapat menjadi alternatif sistem yang dapat dipercaya oleh pakar untuk menggantikannya dalam situasi tertentu.

Certainty Factor merupakan teori yang dapat digunakan untuk mengatasi masalah ketidakpastian dalam penyelesaian sebuah masalah dengan cara mengukur nilai kepercayaan ahli. Metode ini pertama sekali diperkenalkan oleh Shortliffe Buchanan dalam membuat MYCIN yaitu sebuah aplikasi untuk mengidentifikasi bakteri yang menyebabkan infeksi berat, seperti bakteremia dan meningitis. Certainty Factor menunjukkan nilai kepercayaan pakar dengan ukuran 0-1 dimana 0 merupakan nilai terendah yang berarti pasti tidak dan 1 menunjukkan nilai tertinggi yang berarti pasti[14].

Theorema Bayes memberikan hasil penalaran kepakaran berdasarkan nilai probabilitas atau nilai kemungkinan dari sebab-sebab yang terjadi pada data yang dijadikan nilai input dalam penyelesaian permasalahan. Cara kerja metode ini yaitu dengan membandingkan nilai kejadian yang diharapkan terhadap kemungkinan yang akan terjadi[15]. Metode Perbandingan Exponensial (MPE) adalah salah satu metode dari Decision Suport System (DSS) yang digunakan untuk menentukan urutan prioritas alternatif keputusan dengan kriteria jamak. mengkuantifikasikan pendapat seseorang atau lebih dalam skala tertentu. Dengan perhitungan secara eksponensial, perbedaan nilai antara kriteria dapat dibedakan tergantung kepada kemampuan orang yang menilai[16].

\subsection{Analisa Penyakit Kandidiasis}

Sebelum mendiagnosa jenis penyakit kandidiasis yang diderita oleh seseorang, perlu diketahui terlebih dahulu jenis atau macam-macam penyakit yang disebabkan oleh jamur candidia. Pada dasarnya ada beberapa jenis penyakit kandidiasis berdasarkan jenis jamur yang menginfeksi, namun secara garis besar penyakit ini digolongkan ke dalam tiga bagian yaitu sebagai berikut:

Tabel 1. Data Macam-Macam Penyakit Kandidiasis

\begin{tabular}{ccl}
\hline No & Kode Penyakit & Nama Penyakit \\
\hline 1 & P1 & Candidiasis Thrush \\
2 & P2 & Candidiasis Vulvoginal \\
3 & P3 & Candidiasis Cutaneous \\
\hline
\end{tabular}

\subsection{Tahap Akuisisi Pengetahuan}

Tahap ini merupakan kegiatan pengumpulan pengetahuan dari sumber-sumber seperti pakar, buku, jurnal dan 
JURNAL MEDIA INFORMATIKA BUDIDARMA

Volume 5, Nomor 3, Juli 2021, Page 1097-1106

ISSN 2614-5278 (media cetak), ISSN 2548-8368 (media online)

Available Online at https://ejurnal.stmik-budidarma.ac.id/index.php/mib

DOI 10.30865/mib.v5i3.3078

dari berbagai sumber. Pengetahuan yang dikumpulkan berkaitan dengan penelusuran gejala-gejala dari penyakit kandidiasis yang menyerang manusia. Data-data dari berbagai sumber pengetahuan harus diolah sedemikian rupa sehingga menghasilkan solusi yang baik. Rule base merupakan basis pengetahuan yang diakuisisi dari pengetahuan pakar sebagai acuan dalam penerapan sistem pada metode. Berikut adalah basis pengetahuan yang didapatkan dari penyakit kandidiasis:

Tabel 2. Basis Pengetahuan

\begin{tabular}{|c|c|c|c|c|}
\hline No & $\begin{array}{c}\text { Kode } \\
\text { Gejala }\end{array}$ & Gejala Penyakit & $\begin{array}{c}\text { Nama } \\
\text { Penyakit }\end{array}$ & Pengobatan \\
\hline 1 & $\begin{array}{l}\text { G1 } \\
\text { G2 } \\
\text { G3 } \\
\text { G4 } \\
\text { G5 } \\
\text { G6 } \\
\text { G7 } \\
\text { G8 }\end{array}$ & $\begin{array}{l}\text { Kuning di lidah, bibir, dan gusi } \\
\text { Kemerahan di mulut dan tenggorokan } \\
\text { Kulit pecah-pecah di sudut mulut } \\
\text { Nyeri saat menelan. } \\
\text { Gigi keropos } \\
\text { Bibir pecah-pecah } \\
\text { Mual dan muntah } \\
\text { Letih dan lesu }\end{array}$ & $\begin{array}{c}\text { Candidiasis } \\
\text { Thrush }\end{array}$ & $\begin{array}{l}\text { Menggunakan obat anti jamur } \\
\text { Amphotericin B dengan cara injeksi atau } \\
\text { suntik digunakan untuk mengobati jamur } \\
\text { yang ada dimulut. }\end{array}$ \\
\hline 2 & $\begin{array}{l}\text { G9 } \\
\text { G10G11 } \\
\text { G12 } \\
\text { G13 } \\
\text { G14 }\end{array}$ & $\begin{array}{l}\text { Terasa terbakar saat buang air kecil } \\
\text { Terjadi pembengkakan } \\
\text { Rasa gatal yang ekstrim } \\
\text { Keputihan } \\
\text { Kemerah-merahan } \\
\text { Ruam }\end{array}$ & $\begin{array}{c}\text { Candidiasis } \\
\text { Vulvoginal }\end{array}$ & $\begin{array}{l}\text { Oleskan krim anti jamur Clotrimazole } \\
\text { dengan kandungan clotrimazole } 1 \% \text { pada } \\
\text { area luar sekitar anus dan alat kelamin } \\
\text { (anogenital) yang gatal, sebanyak } 2-3 \\
\text { kali sehari, selama } 2 \text { minggu. }\end{array}$ \\
\hline 3 & $\begin{array}{l}\text { G15 } \\
\text { G16 } \\
\text { G17 } \\
\text { G18 } \\
\text { G19 } \\
\text { G20 }\end{array}$ & $\begin{array}{l}\text { Kering } \\
\text { Pecah-pecah } \\
\text { Sakit otot-otot } \\
\text { Suhu tubuh naik turun } \\
\text { Panas tinggi } \\
\text { Kemerah-merahan }\end{array}$ & $\begin{array}{l}\text { Candidiasis } \\
\text { Cutaneous }\end{array}$ & $\begin{array}{l}\text { Taburkan bedak obat anti jamur } \\
\text { Miconazole } 2 \text { kali sehari untuk } \\
\text { mengatasi infeksi jamur pada kulit. }\end{array}$ \\
\hline
\end{tabular}

\subsection{Analisa Basis Pengetahuan}

Basis pengetahuan menjadi hal yang paling utama di dalam sistem pakar. Yang menjadi basis pengetahuan pada metode Certainty Factor adalah fakta-fakta berupa pengetahuan pakar yang menjadi dasar pengetahuan untuk diperiksa dan diperhitungkan dalam mencapai nilai kepastian pada kasus yang dihadapi. Nilai $\mathrm{CF}$ akan didapat dari rumus pengurangan $\mathrm{MB}$ (Measure of belief) yaitu nilai kepercayaan dan $\mathrm{MD}$ (Measure Of Disbelief) atau nilai ketidakpercaan[17]. Sama seperti CF, basis pengetahuan pada Theorema Bayes juga berupa fakta-fakta pengetahuan pakar yang menjadi acuan untuk diperhitungkan. Namun pada Theorema Bayes, cara untuk mendapatkan hasil dari keputusan adalah dengan memperhitungkan nilai probabilitas berupa kemungkinan berdasarkan hipotesa. Nilai probabilitas di dapat dengan membagikan nilai probabilitas hipotesa tanpa memandang evidence dengan probabilitas evidence yang ada[18].

\section{HASIL DAN PEMBAHASAN}

Dalam penelitian ini hasil dan pembahasan bagaimana pengujian dilaksanakan untuk mengetahui bagaimana Certainty Factor dan Theorema Bayes dapat memberikan hasil diagnosa pada penyakit kandidiasis, kemudian dari kedua metode tersebut yang manakah diantara keduanya yang akurat dalam memberika solusi yang tepat. Perhitungan dilakukan dengan menganalisa basis pengetahuan yang ada berupa fakta-fakta pengetahuan pakar yang sama untuk kedua metode tersebut, kemudian menghitung dengan masing-masing rumus yang ada. Hasil dari keduanya dapat dianalisa dan dibandingkan dengan metode perbandingan eksponensial.

\subsection{Pembentukan aturan}

Dengan aturan yang dibentuk akan memudahkan dalam analisa. Aturan berikut merupakan dasar dari diagnosa penyakit kandidiasis yang berlaku untuk kedua metode yang akan diterapkan:

Tabel 3. Pembentukan Aturan

\begin{tabular}{llllc}
\hline No & Kode & Nama Gejala & \multicolumn{2}{c}{ Jenis Penyakit } \\
& Gejala & & P1 & P2 \\
\hline 1 & G1 & Kuning di lidah, bibir, dan gusi & $\checkmark$ & \\
2 & G2 & Kemerahan di mulut dan tenggorokan & $\checkmark$ & \\
3 & G3 & Kulit pecah-pecah di sudut mulut & $\checkmark$ & \\
4 & G4 & Nyeri saat menelan. & $\checkmark$ & \\
\hline
\end{tabular}


JURNAL MEDIA INFORMATIKA BUDIDARMA

Volume 5, Nomor 3, Juli 2021, Page 1097-1106

ISSN 2614-5278 (media cetak), ISSN 2548-8368 (media online)

Available Online at https://ejurnal.stmik-budidarma.ac.id/index.php/mib DOI $10.30865 / \mathrm{mib} . v 5 i 3.3078$

\begin{tabular}{|c|c|c|c|c|c|}
\hline \multirow[t]{2}{*}{ No } & \multirow{2}{*}{$\begin{array}{l}\text { Kode } \\
\text { Gejala }\end{array}$} & \multirow[t]{2}{*}{ Nama Gejala } & \multicolumn{3}{|c|}{ Jenis Penyakit } \\
\hline & & & $\mathrm{P} 1$ & $\mathrm{P} 2$ & P3 \\
\hline 5 & G5 & Gigi keropos & $\checkmark$ & & \\
\hline 6 & G6 & Bibir pecah-pecah & $\checkmark$ & & \\
\hline 7 & G7 & Mual dan muntah & $\checkmark$ & & \\
\hline 8 & G8 & Letih dan lesu & $\checkmark$ & & \\
\hline 9 & G9 & Terasa terbakar saat buang air kecil & & $\checkmark$ & \\
\hline 10 & G10 & Terjadi pembengkakan & & $\checkmark$ & \\
\hline 11 & G11 & Rasa gatal yang ekstrim & & $\checkmark$ & \\
\hline 12 & G12 & Keputihan & & $\checkmark$ & \\
\hline 13 & G13 & Kemerah-merahan & & $\checkmark$ & \\
\hline 14 & G14 & Ruam & & $\checkmark$ & \\
\hline 15 & G15 & Kering & & & $\checkmark$ \\
\hline 16 & G16 & Pecah-pecah & & & $\checkmark$ \\
\hline 17 & G17 & Sakit otot-otot & & & $\checkmark$ \\
\hline 18 & G18 & Suhu tubuh naik turun & & & $\checkmark$ \\
\hline 19 & G19 & Panas tinggi & & & $\checkmark$ \\
\hline 20 & G20 & Kemerah-merahan & & & $\checkmark$ \\
\hline
\end{tabular}

Berdasarkan penelitian pada fakta yang terjadi dari 175 populasi yang mengalami penyakit kandidiasis, didapatkan data sebagai berikut:

Tabel 4. Penyakit Kandidiasis

\begin{tabular}{lll}
\hline No & Jenis penyakit & Jumlah kasus Terjangkit \\
\hline 1 & Candidiasis Thrush & 80 \\
2 & Candidiasis Vulvoginal & 55 \\
3 & Candidiasis Cutaneous & 40 \\
JUMLAH & 175 \\
\hline
\end{tabular}

\subsection{Penerapan Metode Certainty Factor}

Certainty Factor merupakan metode yang menyatakan tingkat kepercayaan dalam suatu kejadian atau yang biasa disebut dengan fakta atau hipotesa berdasarkan fakta dari bukti-bukti. Untuk mengasumsikan derajat keyakinan seorang pakar terhadap suatu data, maka dibuatlah penilaian sebagai berikut [14]:

Dimana:

$$
C F[H, E]=M B[H, E]-M D[H, E]
$$

$$
\begin{aligned}
& M B[H, E]=\frac{\max [\mathrm{P}(\mathrm{H} \mid \mathrm{E}), \mathrm{P}(\mathrm{H})]-\mathrm{P}(\mathrm{H})}{\operatorname{Max}[1,0]-\mathrm{P}(\mathrm{H})} \\
& \operatorname{MD}(\mathrm{H}, \mathrm{E})=\frac{\min [\mathrm{P}(\mathrm{H} \mid \mathrm{E}), \mathrm{P}(\mathrm{H})]-\mathrm{P}(\mathrm{H})}{\operatorname{Min}[1,0]-\mathrm{P}(\mathrm{H})}
\end{aligned}
$$

Certainty Factor untuk kaidah dengan kesimpulan yang serupa (similarly concluded rules) :

$$
\mathrm{CF} \text { combineCF}[\mathrm{H}, \mathrm{E}] 1,2=\mathrm{CF}[\mathrm{H}, \mathrm{E}] 1+\mathrm{CF}[\mathrm{H}, \mathrm{E}] 2 *[1-\mathrm{CF}[\mathrm{H}, \mathrm{E}] 1]
$$

Keterangan:

$\mathrm{CF}[\mathrm{H}, \mathrm{E}] \quad$ : Certainty factor hipotesa yang dipengaruhi oleh evidence e diketahui dengan pasti

$\mathrm{MB}[\mathrm{H}, \mathrm{E}] \quad$ : Measure of belief terhadap hipotesa $\mathrm{H}$, jika diberikan evidence $\mathrm{E}$ (antara 0 dan 1 )

$\mathrm{MD}[\mathrm{H}, \mathrm{E}] \quad$ : Measure of disbelief terhadap evidebce $\mathrm{H}$, jika diberikan evidance $\mathrm{E}$ (antara 0 dan 1 )

Certainty factor untuk kaidah premis tunggal

$\mathrm{P}(\mathrm{H}) \quad$ : Probabilitas kejadian berdasarkan hipotesa

Adapun nilai kepercayaan antara 0 dan 1 memiliki bobot sebagai berikut [19]:

Tabel 5. Nilai Kepercayaan

\subsubsection{Menentukan nilai CF}

\begin{tabular}{llc}
\hline No & Keterangan & Nilai \\
\hline 1 & Tidak & 0 \\
2 & Tidak Tahu & 0,2 \\
3 & Sedikit Yakin & 0,4 \\
4 & Cukup Yakin & 0,6 \\
5 & Yakin & 0,8 \\
6 & Sangat Yakin & 1 \\
\hline
\end{tabular}

Untuk menentukan nilai CF maka digunakan data yang ada pada rumusan yang telah ditentukan. Adapun 


\section{JURNAL MEDIA INFORMATIKA BUDIDARMA}

Volume 5, Nomor 3, Juli 2021, Page 1097-1106

ISSN 2614-5278 (media cetak), ISSN 2548-8368 (media online)

Available Online at https://ejurnal.stmik-budidarma.ac.id/index.php/mib DOI 10.30865/mib.v5i3.3078

tahapannya adalah sebagai berikut :

1. Menentukan nilai $\mathrm{P}(\mathrm{H})$ untuk setiap penyakit

Nilai probabilitas setiap penyakit diambil dari nilai kasus yang terjadi terhadap sample yang diteliti dengan rumusan sebagai berikut :

$$
\begin{gathered}
P(H, E 1)=\frac{P(H)}{P(E)}=\frac{80}{175}=0,45 \\
P(H, E 1)=\frac{P(H)}{P(E)}=\frac{55}{175}=0,31 \\
P(H, E 1)=\frac{P(H)}{P(E)}=\frac{40}{175}=0,22
\end{gathered}
$$

2. Menentukan nilai $\mathrm{P}(\mathrm{H})$ untuk setiap gejala

Nilai probabilitas pada setiap gejala diambil dari banyaknya penderita yang mengalami gejala tersebut dibagi dengan jumlah pasien yang mengalami penyakit pada rule yang bersangkutan. (Data ini diambil dari studi kasus di lapangan)

$$
\begin{aligned}
& P(H, E 1)=\frac{P(H)}{P(E)}=\frac{50}{80}=0,62 \\
& P(H, E 2)=\frac{P(H)}{P(E)}=\frac{45}{80}=0,56 \\
& P(H, E 3)=\frac{P(H)}{P(E)}=\frac{39}{80}=0,48 \\
& P(H, E 4)=\frac{P(H)}{P(E)}=\frac{53}{80}=0,66 \\
& P(H, E 5)=\frac{P(H)}{P(E)}=\frac{50}{80}=0,62 \\
& P(H, E 6)=\frac{P(H)}{P(E)}=\frac{78}{80}=0,97 \\
& P(H, E 7)=\frac{P(H)}{P(E)}=\frac{66}{80}=0,82 \\
& P(H, E 16)=\frac{P(H)}{P(E)}=\frac{35}{40}=0,87 \\
& P(H, E 14)=\frac{P(H)}{P(E)}=\frac{27}{55}=0,49 \\
& P(H, E 12)=\frac{P 3}{P(E)}=0,53 \\
& P(H, E 9)=\frac{P(H)}{P(E)}=\frac{50}{55}=0,90 \\
& P(H, E 10)=\frac{P(H)}{P(E)}=\frac{48}{55}=0,87 \\
& P(H)
\end{aligned}
$$


ISSN 2614-5278 (media cetak), ISSN 2548-8368 (media online)

Available Online at https://ejurnal.stmik-budidarma.ac.id/index.php/mib DOI 10.30865/mib.v5i3.3078

$$
\begin{aligned}
& P(H, E 17)=\frac{P(H)}{P(E)}=\frac{30}{40}=0,75 \\
& P(H, E 18)=\frac{P(H)}{P(E)}=\frac{15}{40}=0,37 \\
& P(H, E 19)=\frac{P(H)}{P(E)}=\frac{13}{40}=0,32 \\
& P(H, E 20)=\frac{P(H)}{P(E)}=\frac{39}{40}=0,97
\end{aligned}
$$

3. Menetukan nilai $\mathrm{MB}[\mathrm{H}, \mathrm{E}]$

Setelah diketahui nilai $\mathrm{P}(\mathrm{H})$ untuk penyakit dan semua gejala, maka diimplementasikan lah rumus berikut :

$$
\begin{aligned}
& M B[H, E]=\frac{\max [\mathrm{P}(\mathrm{H} \mid \mathrm{E}), \mathrm{P}(\mathrm{H})]-\mathrm{P}(\mathrm{H})}{\operatorname{Max}[1,0]-\mathrm{P}(\mathrm{H})} \\
& M B[H, E 1]=\frac{\max [0.62,0.45]-0.45}{\operatorname{Max}[1,0]-0.45}=0.30
\end{aligned}
$$

Kemudian Nilai MB dicari untuk setiap gejala.

4. Menentukan nilai MD[H,E]

Selanjutnya, dicari nilai MD [H,E] sebagai berikut :

$$
\begin{aligned}
& \operatorname{MD}(\mathrm{H}, \mathrm{E})=\frac{\min [\mathrm{P}(\mathrm{H} \mid \mathrm{E}), \mathrm{P}(\mathrm{H})]-\mathrm{P}(\mathrm{H})}{\operatorname{Min}[1,0]-\mathrm{P}(\mathrm{H})} \\
& \operatorname{MD}(\mathrm{H}, \mathrm{E})=\frac{\min [0.97,0.22]-0.22}{\operatorname{Min}[1,0]-0.22}=0
\end{aligned}
$$

\begin{tabular}{|c|c|c|c|c|c|}
\hline No & $\begin{array}{l}\text { Kode } \\
\text { Gejala }\end{array}$ & Nama Gejala & MB & MD & $\mathrm{CF}$ \\
\hline 1 & G1 & Kuning di lidah, bibir, dan gusi & 0.30 & 0 & 0.30 \\
\hline 2 & $\mathrm{G} 2$ & Kemerahan di mulut dan tenggorokan & 0.2 & 0 & 0.2 \\
\hline 3 & G3 & Kulit pecah-pecah di sudut mulut & 0.05 & 0 & 0.05 \\
\hline 4 & G4 & Nyeri saat menelan. & 0.38 & 0 & 0.38 \\
\hline 5 & G5 & Gigi keropos & 0.30 & 0 & 0.30 \\
\hline 6 & G6 & Bibir pecah-pecah & 0.94 & 0 & 0.94 \\
\hline 7 & G7 & Mual dan muntah & 0.67 & 0 & 0.67 \\
\hline 8 & G8 & Letih dan lesu & 0.14 & 0 & 0.14 \\
\hline 9 & G9 & Terasa terbakar saat buang air kecil & 0.85 & 0 & 0.85 \\
\hline 10 & G10 & Terjadi pembengkakan & 0.81 & 0 & 0.81 \\
\hline 11 & G11 & Rasa gatal yang ekstrim & 0.72 & 0 & 0.72 \\
\hline 12 & G12 & Keputihan & 0.56 & 0 & 0.56 \\
\hline 13 & G13 & Kemerah-merahan & 0.33 & 0 & 0.33 \\
\hline 14 & G14 & Ruam & 0.26 & 0 & 0.26 \\
\hline 15 & G15 & Kering & 0.66 & 0 & 0.66 \\
\hline 16 & G16 & Pecah-pecah & 0.83 & 0 & 0.83 \\
\hline 17 & G17 & Sakit otot-otot & 0.67 & 0 & 0.67 \\
\hline 18 & G18 & Suhu tubuh naik turun & 0.19 & 0 & 0.19 \\
\hline 19 & G19 & Panas tinggi & 0.12 & 0 & 0.12 \\
\hline 20 & $\mathrm{G} 20$ & Kemerah-merahan & 0.96 & 0 & 0.96 \\
\hline
\end{tabular}

Lanjutkan perhitungan hingga nilai seluruh MD diketahui. Karena nilai pembagi pada rumus ini adalah nilai minimum yaitu 0 maka hasilnya adalah 0 .

5. Menentukan nilai $\mathrm{CF}$

Rumus mencari nilai pakar yaitu dengan mengurangkan nilai MB dan MD yang telah didapatkan sebelumnya, hasil pengurangan inilah yang disebut dengan nilai $\mathrm{CF}$ untuk setiap gejala :

$$
\begin{aligned}
& C F[H, E]=M B[H, E]-M D[H, E] \\
& C F[H, E]=0.30-0=0.30
\end{aligned}
$$

Tabel 6. Nilai CF 


\section{JURNAL MEDIA INFORMATIKA BUDIDARMA}

Volume 5, Nomor 3, Juli 2021, Page 1097-1106

ISSN 2614-5278 (media cetak), ISSN 2548-8368 (media online)

Available Online at https://ejurnal.stmik-budidarma.ac.id/index.php/mib DOI 10.30865/mib.v5i3.3078

Pada studi kasus ini seseorang diduga terinfeksi kandidiasis. Berikut adalah gejala-gejala yang dialami pasien :

1. Kuning di gusi, lidah (G1)

2. Kemerah-merahan $(\mathrm{G} 2)$

3. Mual dan muntah (G7)

4. Terasa terbakar saat buang air kecil (G9)

5. Rasa gatal yang ekstrim (G11)

6. Kemerah-merahan didaerah vagina (G13)

7. Ruam (G14)

8. Bibir kering (G15)

9. Otot-otot sakit/pegal (G17)

10. Kemerah-merahan di daerah mulut (G20)

Untuk mengetahui jenis penyakit yang diderita, Nilai CF dari seluruh gejala-gejala yang dialami kemudian akan kita masukkan ke dalam rumus combine sebagai berikut :

a. Gejala yang mengindikasikan pada P1 adalah : (G1, G2, dan G7)

$$
\begin{aligned}
& \mathrm{CF}_{\text {combine }} \mathrm{CF}[\mathrm{H}, \mathrm{E}]_{1,2}=\mathrm{CF}[\mathrm{H}, \mathrm{E}]_{1}+\mathrm{CF}[\mathrm{H}, \mathrm{E}]_{2} *\left[1-\mathrm{CF}[\mathrm{H}, \mathrm{E}]_{1}\right] \\
& \left.\mathrm{CF}_{\text {combine }} \mathrm{CF}[\mathrm{H}, \mathrm{E}]_{1,2}=0.30+0.2 *[1-0.30]=0.44 \text { (old } 1\right) \\
& \mathrm{CF}_{\text {combine }} \mathrm{CF}[\mathrm{H}, \mathrm{E}]_{\text {old }}, 7=0.44+0.67 *[1-0.44]=0.8115
\end{aligned}
$$

sMaka nilai kepercayaan terhadap P1 adalah $0.8115 \times 100 \%=81,15 \%$

b. Gejala yang mengindikasikan pada P2 adalah : (G9, G11, G13 dan G14)

$$
\begin{aligned}
& \mathrm{CF}_{\text {combine }} \mathrm{CF}[\mathrm{H}, \mathrm{E}] 9,11=\mathrm{CF}[\mathrm{H}, \mathrm{E}] 9+\mathrm{CF}[\mathrm{H}, \mathrm{E}]_{11} *[1-\mathrm{CF}[\mathrm{H}, \mathrm{E}] 9] \\
& \mathrm{CF}_{\text {combine }} \mathrm{CF}[\mathrm{H}, \mathrm{E}] 9,11=0.85+0.72 *[1-0.85]=0.958(\text { old } 1) \\
& \left.\mathrm{CF}_{\text {combine }} \mathrm{CF}[\mathrm{H}, \mathrm{E}]\right]_{\text {old }}, 13=0.958+0.33 *[1-0.958]=0.9718(\text { old } 2) \\
& \left.\mathrm{CF}_{\text {combine }} \mathrm{CF}[\mathrm{H}, \mathrm{E}]\right]_{\mathrm{old}}, 14=0.9718+0.26 *[1-0.9718]=0.9791
\end{aligned}
$$

Maka nilai kepercayaan terhadap P2 adalah $0.9791 \times 100 \%=97,91 \%$

c. Gejala yang mengindikasikan pada P3 adalah : (G15, G17, dan G20)

$$
\begin{aligned}
& \mathrm{CF}_{\text {combine }} \mathrm{CF}[\mathrm{H}, \mathrm{E}]_{15,17}=\mathrm{CF}[\mathrm{H}, \mathrm{E}]_{15}+\mathrm{CF}[\mathrm{H}, \mathrm{E}]_{17} *[1-\mathrm{CF}[\mathrm{H}, \mathrm{E}] 15] \\
& \mathrm{CF}_{\text {combine }} \mathrm{CF}[\mathrm{H}, \mathrm{E}]_{15,17}=0.66+0.67 *[1-0.66]=0.8878(\text { old } 1) \\
& \mathrm{CF}_{\text {combine }} \mathrm{CF}[\mathrm{H}, \mathrm{E}]_{\text {old }_{1,2}}=0.8878+0.96 *[1-0.8878]=0.9955
\end{aligned}
$$

Maka nilai kepercayaan terhadap P3 adalah 0.9955 x $100 \%=99.55 \%$

Dari kesemua nilai yang dihasilkan, maka nilai keyakinan yang paling besar ada pada P3 yaitu penyakit candidiasis cutaneous.

\subsection{Penerapan dengan Theorema Bayes}

Theorema Bayes merupakan metode yang digunakan untuk mengidentifikasi nilai probabilitas suatu permasalahan berdasarkan data yang didapatkan dari observasi yang dilakukan. Oleh karena itu untuk mendapatkan hasil keputusan dari data yang didapatkan maka dilakukan pengamatan. Setelah pengamatan dilakukan, informasi dalam nilai distribusi awal dikombinasikan dengan informasi dengan data sampel melalui Theorema Bayes [5]. Probabilitas bayes merupakan salah satu cara untuk mengatasi ketidakpastian data dengan menggunakan Formula bayes yang dinyatakan dengan:

Keterangan :

$$
P(H, E 1)=\frac{P(E, H) \cdot P(H)}{P(E)}
$$

$\mathrm{P}(\mathrm{H}, \mathrm{E})=$ probabilitas hipotesis $\mathrm{H}$ jika diberikan evidence $\mathrm{E}$

$\mathrm{P}(\mathrm{E}, \mathrm{H})=$ probailitas munculnya evidence $\mathrm{E}$ jika diketahui hipotesis $\mathrm{H}$

$\mathrm{P}(\mathrm{H}) \quad=$ probabilitas $\mathrm{H}$ tanpa mengandung evidence apapun

$\mathrm{P}(\mathrm{E}) \quad=$ probabilitas evidence $\mathrm{E}$

Berikut tahapan yang dilakukan dalam mendiagnosa penyakit kandidiasis berdasarkan studi kasus di atas dengan Theorema Bayes:

1. Menentukan nilai probabilitas setiap gejala

Nilai probabilitas setiap gejala telah didapatkan saat menyelesaikan kasus dengan metode Certainty Factor.

2. Menjumlahkan nilai probabilitas setiap penyakit dari gejala yang ada 


\section{JURNAL MEDIA INFORMATIKA BUDIDARMA}

Volume 5, Nomor 3, Juli 2021, Page 1097-1106

ISSN 2614-5278 (media cetak), ISSN 2548-8368 (media online)

Available Online at https://ejurnal.stmik-budidarma.ac.id/index.php/mib DOI 10.30865/mib.v5i3.3078

$$
\begin{aligned}
& \mathrm{P} 1=0.62+0.56+0.48+0.66+0.62+0.97+0.82+0.53=5.26 \\
& \mathrm{P} 2=0.90+0.87+0.81+0.70+0.54+0.49=4.31 \\
& \mathrm{P} 3=0.95+0.87+0.75+0.37+0.32+0.97=4.23
\end{aligned}
$$

3. Mencari nilai probabilitas $\mathrm{H}$

Tahap ini dilakukan dengan membagikan nilai setiap gejala dengan nilai probabilitas setiap penyakit.

$$
\begin{aligned}
& P 1=\left(\frac{0.62}{5.26}\right) x 0.62+\left(\frac{0.56}{5.26}\right) \times 0.56+\left(\frac{0.48}{5.26}\right) x 0.48+\left(\frac{0.66}{5.26}\right) x 0.66+\left(\frac{0.62}{5.26}\right) x 0.62+\left(\frac{0.97}{5.26}\right) \times 0.97 \\
& +\left(\frac{0.82}{5.26}\right) \times 0.82+\left(\frac{0.53}{5.26}\right) \times 0.53=0.62 \\
& P 2=\left(\frac{0.90}{4.31}\right) x 0.90+\left(\frac{0.87}{4.31}\right) x 0.87+\left(\frac{0.81}{4.31}\right) x 0.81+\left(\frac{0.70}{4.31}\right) x 0.70+\left(\frac{0.54}{4.31}\right) x 0.54+\left(\frac{0.49}{4.31}\right) x 0.4=0.71 \\
& P 3=\left(\frac{0.95}{4.23}\right) \times 0.95+\left(\frac{0.87}{4.23}\right) \times 0.87+\left(\frac{0.75}{4.23}\right) \times 0.75+\left(\frac{0.37}{4.23}\right) \times 0.37+\left(\frac{0.32}{4.23}\right) x 0.32+\left(\frac{0.97}{4.23}\right) x 0.9=0.76
\end{aligned}
$$

4. Mencari nilai kesimpulan berdasarkan study kasus

$$
\begin{aligned}
& P 1=\left(\frac{0.62 \times 0.11}{0.62}\right) \times 0.62+\left(\frac{0.56 \times 0.10}{0.62}\right) \times 0.56+\left(\frac{0.82 \times 0.10}{0.62}\right) \times 0.82=0.24 \\
& P 2=\left(\frac{0.90 \times 0.20}{0.71}\right) \times 0.90+\left(\frac{0.81 \times 0.18}{0.71}\right) \times 0.81+\left(\frac{0.54 \times 0.12}{0.71}\right) \times 0.54+\left(\frac{0.49 \times 0.11}{0.71}\right) \times 0.49=0.44 \\
& P 3=\left(\frac{0.95 \times 0.22}{0.76}\right) \times 0.95+\left(\frac{0.75 \times 0.17}{0.76}\right) \times 0.75+\left(\frac{0.97 \times 0.23}{0.76}\right) \times 0.49=0.62
\end{aligned}
$$

Dari hasil yang di dapat, kemungkinan pasien menderita P1 adalah 24\%, P2 sebanyak 44\%, dan P3 sebesar $62 \%$. Jadi pasien lebih tinggi kemungkinannya mengalami penyakit kandidiasis couteneous.

\subsection{Penerapan Metode Perbandingan Ekponensial}

Dalam menerapkan metode perbandingan eksponensial, ada beberapa langkah yang harus diselesaikan, sebagai berikut :

1. Menentukan nilai alternatif

Adapun alternatif disini adalah :

a. Metode Certainty Factor

b. Theorema Bayes.

2. Menetukan kriteria

Kriteria yang dimiliki oleh kedua metode tersebut adalah :

a. Jumlah langkah-langkah yang digunakan

b. Jumlah gejala pada penyakit

3. Menetukan bobot

Bobot merupakan hal yang penting untuk dibuat dan diberi nilainya berdasarkan kepentingan dari kriteria yang ada. Karena kedua kriteria ini sama pentingnya, gejala penyakit sama, dan langkah-langkah juga mendekati kemiripan dalam banyaknya step yang dilalui, maka dibuatlah bobot kedua kriteria bernilai sama yaitu $50 \%$.

4. Memberikan nilai dan menghitung skor

Setelah semua hal-hal di atas diselesaikan, maka saatnya memberikan nilai untuk mendapatkan rangking.

Tabel 7. Nilai Perbandiangan

\begin{tabular}{lllllll}
\hline No & Alternatif & $\begin{array}{l}\text { Hasil } \\
\text { diagnosa }\end{array}$ & $\begin{array}{l}\text { Pengaruh } \\
\text { kriteria }\end{array}$ & Bobot & Perhitungan & Rangking \\
\hline 1 & Certainty Factor & 99,55 & $50 \%$ & 0.5 & $99,55^{(0.5)}=9,97$ & 1 \\
2 & Theorema Bayes & 62 & $50 \%$ & 0.5 & $62^{(0.5)}=7,87$ & 2 \\
\hline
\end{tabular}

\subsection{Hasil Penelitian}

Berdasarkan tahapan yang telah dilakukan pada penelitian ini, maka didapatlah bahwa :

1. Hasil kedua uji coba dengan metode Certainty Factor dan Theorema Bayes adalah sama yaitu tingkat persentase terendah ada pada penyakit Candidiasis Truth, kemudian Candidiasis Vuvoginal, dan yang paling tinggi Candidiasis Cutaneous.

Tabel 8. Hasil Perhitungan

\begin{tabular}{lllc}
\hline No & Nama Penyakit & \multicolumn{2}{c}{ Hasil diagnosa pada kasus pasien } \\
& & Certainty Factor & Theorema Bayes \\
\hline 1 & Candidiasis Thrush & $81,15 \%$ & $24 \%$ \\
\hline
\end{tabular}


JURNAL MEDIA INFORMATIKA BUDIDARMA

Volume 5, Nomor 3, Juli 2021, Page 1097-1106

ISSN 2614-5278 (media cetak), ISSN 2548-8368 (media online)

Available Online at https://ejurnal.stmik-budidarma.ac.id/index.php/mib

DOI 10.30865/mib.v5i3.3078

\begin{tabular}{lllc}
\hline No & Nama Penyakit & \multicolumn{2}{c}{ Hasil diagnosa pada kasus pasien } \\
& & Certainty Factor & Theorema Bayes \\
\hline 2 & Candidiasis Vulvoginal & $97,91 \%$ & $44 \%$ \\
3 & Candidiasis Cuteneous & $99,55 \%$ & $62 \%$ \\
\hline
\end{tabular}

2. Hasil perbandingan kedua metode ini dengan metode perbandingan exponensial menunjukkan bahwa metode Certainty Factor lebih akurat dalam mendiagnosa penyakit kandidiasis.

\section{KESIMPULAN}

Berdasarkan hasil penelitian yang telah dilakukan terhadap sample yang sama, dapat diambil kesimpulan bahwa Metode Certainty factor dan theorema bayes dapat digunakan untuk mendiagnosa penyakit kandidiasis. Kemudian, setelah dilakukan perbandingan dengan metode perbandingan eksponensial, maka disimpulkan bahwa metode Certainty Factor lebih akurat dalam mendiagnosa penyakit kandidiasis. Oleh karena itu, maka metode Certainty Factor adalah metode yang lebih direkomendasikan untuk dipakai dalam mendiagnosa penyakit kandidiasis atau penyakit lainnya dalam penelitian sejenis pada masa yang akan datang.

\section{REFERENCES}

[1] K. F. Kalista, L. K. Chen, R. Wahyuningsih, and C. M. Rumende, "Karakteristik Klinis dan Prevalensi Pasien Kandidiasis Invasif di Rumah Sakit Cipto Mangunkusumo,” J. Penyakit Dalam Indones., vol. 4, no. 2, p. 56, 2017, doi: 10.7454/jpdi.v4i2.104.

[2] D. Flamandita, M. Sahlan, K. Lischer, and D. K. Pratami, "Molecular Docking Analysis of Anti-Candida albicans Biomarkers in Sulawesi Propolis Against Secreted Aspartic Proteinase-5," ICETAS 2019 - 2019 6th IEEE Int. Conf. Eng. Technol. Appl. Sci., 2019, doi: 10.1109/ICETAS48360.2019.9117300.

[3] M. Provinsi and L. Tahun, "HUBUNGAN KEBIASAAN SEHARI-HARI DENGAN TIMBULNYA KEJADIAN KANDIDIASIS INTERTRIGO PADA PASIEN RAWAT JALAN DI RUMAH SAKIT UMUM DR . H . ABDOEL,' vol. 2, no. 4, pp. 169-176, 2015.

[4] A. Andriani, A. Meyliana, Sardiarinto, W. E. Susanto, and Supriyanta, "Certainty Factors in Expert System to Diagnose Disease of Chili Plants," 2018 6th Int. Conf. Cyber IT Serv. Manag. CITSM 2018, no. Citsm, pp. 1-6, 2019, doi: 10.1109/CITSM.2018.8674264.

[5] R. Syahrin, S. T. Informatika, T. Bayes, and P. Gastrointestinal, "Model Aplikasi Sistem Pakar Untuk Mendiagnosa Penyakit Gastrointestinal," pp. 1-10, 2018.

[6] T. Informatika, U. M. Sidoarjo, J. R. Gelam, and C. Sidoarjo, "Dengan Metode “ Certainty Factor ,” 2015.

[7] M. Ramadhan and H. Winata, "Sistem Pakar Mendiagnosa Gangguna Fungsi Kardiovaskular Dengan Metode Theorema Bayes," vol. 513, no. 1, pp. 510-513, 2019.

[8] I. Siahaan, "Perbandingan metode certainty factor dan bayes dalam mendiagnosa penyakit angina pektoris menggunakan metode perbandingan eksponensial," Pelita Inform. Inf. dan Inform., vol. 6, no. 2, pp. 193-199, 2017, [Online]. Available: https://ejurnal.stmik-budidarma.ac.id/index.php/pelita/article/view/580/552.

[9] W. Uriawan, A. R. Atmadja, M. Irfan, I. Taufik, and N. J. Luhung, "Comparison of Certainty Factor and Forward Chaining for Early Diagnosis of Cats Skin Diseases," 2018 6th Int. Conf. Cyber IT Serv. Manag. CITSM 2018, no. Citsm, pp. 1-7, 2019, doi: 10.1109/CITSM.2018.8674381.

[10] C. R. Amanda Patria, "Analisa Perbandingan Metode Certainty Factor dan Dempster Shafer pada Sistem Pakar Diagnosa Penyakit Diabetes Melitus,” p. 283, 2015.

[11] W. Yulianti, D. Arisandi, and A. Syaf, "Comparison of the effectiveness of certainty factor vs dempster-shafer in the determination of the adolescent learning styles," Proc. - 2018 2nd Int. Conf. Electr. Eng. Informatics Towar. Most Effic. W. Mak. Deal. with Futur. Electr. Power Syst. Big Data Anal. ICon EEI 2018, no. October, pp. 46-50, 2018, doi: 10.1109/ICon-EEI.2018.8784313.

[12] Z. Gaib, "Faktor - Faktor Yang Berpengaruh Terhadap Terjadinya Kandidiasis Eritematosa Pada Pengguna Gigitiruan Lengkap," $e$-GIGI, vol. 1, no. 2, 2013, doi: 10.35790/eg.1.2.2013.3228.

[13] A. G. Manuputty and L. Astari, "Kandidiasis Vulvovaginalis Pada Anak Dengan Diabetes Melitus Tipe I Departmen Ilmu Kesehatan Kulit dan Kelamin , Fakultas Kedokteran Universitas Airlangga / Rumah Sakit Umum Daerah Dr . Soetomo , Surabaya Corresponding author e-mail: linda.astari@yahoo.c," Departmen Ilmu Kesehat. Kulit dan Kelamin, Fak. Kedokt. Univ. Airlangga, vol. 12, no. 2, pp. 43-51, 2020.

[14] H. Fahmi, A. A. Nababan, M. Jannah, M. Khairani, Y. F. A. Lubis, and S. Fahri, "Analysis of Certainty Factor Methods to Determine Skills in Generation y," Mecn. 2020 - Int. Conf. Mech. Electron. Comput. Ind. Technol., pp. 222-225, 2020, doi: 10.1109/MECnIT48290.2020.9166646.

[15] P. S. Ramadhan, "Sistem Pakar Pendiagnosaan Dermatitis Imun Menggunakan Teorema Bayes," InfoTekJar (Jurnal Nas. Inform. dan Teknol. Jaringan), vol. 3, no. 1, pp. 43-48, 2018, doi: 10.30743/infotekjar.v3i1.643.

[16] R. I. Borman and H. Fauzi, "Dalam Sistem Pendukung Keputusan Penerima Beasiswa," CESS J. Comput. Eng. Syst. Sci., vol. 3, no. 1, pp. 17-22, 2018.

[17] P. Informatika, B. Darma, M. Program, and S. Teknik, "Certainty Factor," Encycl. Oper. Res. Manag. Sci., pp. 160160, 2013, doi: 10.1007/978-1-4419-1153-7_200031.

[18] R. Simalango and A. S. Sinaga, "Diagnosa penyakit ikan hias air tawar dengan Teorema Bayes," J. Penelit. Tek. Inform., vol. 3, no. 1, pp. 43-50, 2018.

[19] Y. Darnita and M. Muntahanah, "Penerapan Algoritma Certainty Factor Tes Kesehatan Sebagai Syarat Kelayakan Mendapatkan Surat Izin Mengemudi (Sim),” Sistemasi, vol. 7, no. 3, p. 176, 2018, doi: 10.32520/stmsi.v7i3.379. 